Research

\title{
Ingredients of Active Compounds and Anti-Diabetic Test of Water Extract of Lannea coromandelica (Houtt) Merr. On Wistar Rats
}

\author{
Nona Rahmaida Puetri',2*, Rita Marleta Dewi, Sahrul³, Yasir', Munawir Annasri' \\ ${ }^{1}$ Aceh Health Research and Development Institute, NIHRD MoH Indonesian Republic \\ ${ }^{2}$ Program Study of Veterinary Public Health, Faculty of Veterinary Medicine, Universitas Syiah Kuala, Aceh \\ ${ }^{3}$ Centre for Biomedical and Basic Health Technology, NIHRD MoH Indonesian Republic \\ *Corresponding author: nona.rahmaidapuetri@gmail.com \\ Submitted April 1, 2021 Accepted May 3, 2021
}

\begin{abstract}
Leaves of Lannea coromandelica (Houtt.) Merr. is one of the plants found in Aceh. This study aims to determine the effect of giving water extract of Lannea coromandellica (Houtt.) Merr. against STZ-induced blood sugar levels of wistar rats. The experimental study used a sample of 25 male and 15 female Wistar rats. This research is experimental with a sample of 25 male and 15 female of Wistar rats. The treatments were given, namely negative control (aquades), positive control (metformin), $50 \mathrm{mg}$ EALC, $100 \mathrm{mg}$ EALC, and $150 \mathrm{mg}$ EALC. The data obtained will be analyzed by using the Kruskal Wallis test to obtain the effectiveness of the treatment and also a descriptive analysis for the average reduction in blood glucose levels. Macro and histological observations were also carried out on the liver and pancreas. The results obtained from the Kruskal Wallis test results showed that there was no effect of EALC on changes in the decrease in blood glucose levels of wistar rats for 14 days of treatment. Observation of the macro organs showed pancreas had a changes. While the histological observations pancreas and liver showed changes. The results of this study indicate that the effectiveness of EALC is not proven to have an effect, this is presumably because the extract concentration is too small so it is not enough to work optimally. Phytochemical test shows that EALC contains flavonoids, steroids, phenolics, tannins, saponins and alkaloids.
\end{abstract}

Keywords: water extract, Lannea coromandellica, histology, liver, pancreas

\begin{abstract}
ABSTRAK
Daun Lannea coromandelica (Houtt.) Merr. merupakan salah satu tumbuhan yang terdapat di Aceh. Penelitian ini bertujuan untuk melihat pengaruh pemberian ekstrak air Lannea coromandellica (Houtt.) Merr. terhadap kadar gula darah tikus yang diinduksi STZ. Penelitian eksperimental ini menggunakan sampel sebanyak 25 ekor tikus wistar jantan dan 15 ekor betina. Perlakuan yang diberikan yaitu kontrol negatif (aquades), kontrol positif (metformin), $50 \mathrm{mg}$ EALC, $100 \mathrm{mg}$ EALC, dan $150 \mathrm{mg}$ EALC. Data yang diperoleh dianalisis dengan menggunakan uji Kruskal Wallis untuk endapatkan keefektifan pengobatan serta analisis deskriptif rata-rata penurunan kadar glukosa darah. Pengamatan makro dan histologis juga dilakukan pada hati dan pankreas. Hasil yang diperoleh dari uji Kruskal Wallis menunjukkan bahwa tidak ada pengaruh EALC terhadap perubahan penurunan kadar glukosa darah tikus wistar selama 14 hari perlakuan. Pengamatan organ makro menunjukkan pankreas mengalami perubahan. Sedangkan pengamatan histologis pankreas dan hati menunjukkan perubahan. Hasil penelitian ini menunjukkan bahwa keefektifan EALC tidak terbukti berpengaruh, hal ini diduga karena konsentrasi ekstrak yang terlalu kecil sehingga kurang bekerja secara maksimal. Uji fitokimia menunjukkan bahwa EALC mengandung flavonoid, steroid, fenolat, tanin, saponin dan alkaloid.
\end{abstract}

Kata kunci: air ekstrak, Lannea coromandellica, histologi, hati, pankreas 


\section{INTRODUCTION}

Indonesia is a region located on the equator and has a tropical climate. This situation provides good luck for the Indonesian state, one of which is the diversity of animal and plant biology and of course many plants that are used for medicine (Widiyastuti, 2011). Medicines derived from plants are also known as herbal medicines. In plants there are various chemical / secondary metabolites, some of these metabolites can provide benefits to human health (Saparinto \& Susiana, 2016).

Leaf of Lannea coromandelica (Houtt.) Merr. synonym Lannea grandis Engl. is one of the many plants found in Aceh. In general, the people of Aceh use this plant as a yard fence, but there are also those who use this plant as raw material for traditional medicine and a mixture of cooking ingredients. This plant is a tall tree measuring $10-15 \mathrm{~m}$, with white taproot. Has woody stems, round and branched, green leaves. compound, pinnate with five to fifteen leaflets, opposite each other, has a short petiole, elongated round leaf shape with a tapered tip and base of leaves (Depkes, 2001)

Herbal medicines from plants that are widely used by the public are important to know their effects, therefore it is necessary to test their safety. Toxicity test is one that is indispensable to determine the effect of chemicals on biological materials, especially humans. The stages in the toxicity test are as follows. : (1) Acute Test (single dose), (2) Subchronic Test (daily dose), (3) Chronic Test (daily dose), (4) Special Test (for potentiation with other chemicals, for effects on reproduction, for teratogenicity, for carcinogenicity, for mutagenicity, for skin and eye effects and for behavioral effects) (Loomis \& Ted, 1978)

Several studies of Lannea coromandellica leaf extract that have been conducted at the Aceh Biomedical Research and Development Center (now Balai Litbangkes Aceh) are: Research by Nona and Marlinda on 2016 concerning the effect of giving Lannea coromandelica leaf ethanol extract on changes in blood sugar levels of alloxan injection of Wistar rats (Puetri \& Marlinda, 2017). In 2017, an acute toxicity test was also carried out on the leaf extract of Lannea coromandelica (Houtt.) Merr. With the result that the Lannea coromandellica leaf extract was included in the Practical Non-toxic category according to PERKABPOM No. 7 of 2014 (Yunsa et al., 2017) (BPOM RI, 2014).

The stages that have been passed to determine the effect of giving Lannea coromandellica leaf extract have reached the acute test stage by the researcher and the subchronic test, by Darmansyah (2015). The technique of using medicinal plants that is often used by the community is by boiling it using water. Therefore, researchers are interested in testing the water extract of Lannea coromandellica leaves and testing the active compound content of the leaves so that it is clear whether the water extract of Lannea coromandellica leaves actually has the effect of reducing blood sugar levels or not, and to determine the active compounds contained in the water extract Lannea coromandellica leaves. The objective of this study was to determine the effectiveness of the use of water extract from the leaves of Lannea coromandelica (Houtt.) Merr. in reducing blood glucose levels.

\section{MATERIAL AND METHODS}

\section{Research Materials}

Preparation of water extracts of Lannea coromandellica leaves

The leaves of Lannea coromandellica that have been plucked from the trees are cleaned of the stems and twigs, then air-dried at room temperature. After drying the leaves are made into powder using a grinding machine. Furthermore, the leaf powder is boiled using a clay pot (according to the boiling technique that is often used by the community) together with distilled water.

\section{Experimental Animals}

The experimental animals used in this study were male and female Wistar rats. With 25 male rats and 15 female rats. 6-8 weeks old, minimum body weight 120 grams and active and not disabled rats. During the research period, rats were given special rat feed produced by the Laboratory of Experimental Animals of the University of Indonesia and Puslitbang BTDK Jakarta and given drinking water ad libitum.

\section{Research Methods}

\section{Phytochemical Testing}

Phytochemical testing was carried out in the Unsyiah Chemistry Faculty of Mathematics and Natural Sciences laboratory. The tests included testing alkaloids, steroids and terpenoids, saponins, flavonoids, as well as phenolic and tannin tests using the Harborne phytochemical method.

\section{Experimental Treatment}

Rats were divided into 5 groups, -Each:

P1: aquades negative control 
P2: positive control metformin

P3: Lannea coromandellica leaf water extract 50 $\mathrm{mg}$

P4: Lannea coromandellica leaf water extract 100 $\mathrm{mg}$

P5: Lannea coromandellica leaf water extract 150 $\mathrm{mg}$

For male rats, each group of 5 rats, while the female rats each group 3 rats. Lannea coromandellica leaf water extract is given once a day using a intragastric tube. Examination of blood glucose levels was carried out on day 7 (post test 1) and day 14 (post test 2). Examination of blood glucose levels using a spectrophotometer. On the 14th day after the last blood collection, the rats were euthanized to take their liver and pancreas for macroscopic and histological observation.

\section{RESULTS AND DISCUSSION}

The results of the phytochemical test can be seen in the Table 1.
Phytochemical test results show only terpenoids are not present in the water extract of Lannea coromandellica leaves or the results are negative, while the compounds of flavonoids, steroids, phenolics, tannins, saponins, and alkaloids are positive in the water extract of the leaves of Lannea coromandellica. Examination of blood glucose levels prior to administration of STZ rats (normal), after induction of STZ and Post Test 1 and Test 2 post, on male and female white mice using methods spectrophotometer can be seen in the following Figure 1 and Figure 2.

Overview of the average change blood glucose in male rats showed that before STZ injection, the highest normal blood glucose value was shown in the water extract group of $150 \mathrm{mg} / \mathrm{kgBW}$ Lannea coromandellica leaves with an average of 114.4. the highest normal glucose levels compared to other groups with an average of 122.5. Observations after STZ injection in male rats, the highest results were shown in the negative control group with distilled water and water extract of Lannea coromandellica leaves $50 \mathrm{mg} / \mathrm{kgBW}$ with an average of 415.2. In female rats the highest glucose levels were shown by the positive control group metformin with an average value of 509.33.

Table 1 Phytochemical Test

\begin{tabular}{ccc}
\hline No & Chemical Content of & Results \\
\hline 1. & Flavonoids & + \\
2. & Terpenoids & + \\
3. & Steroids & + \\
4. & Phenolic & + \\
5. & Tannins & + \\
6. & Saponins & + \\
\hline
\end{tabular}

Keterangan: Nilai rerata dengan huruf superscript yang berbeda dalam satu kolom menunjukkan hasil uji lanjut Anova yang berbeda nyata $(\mathrm{P}<0.05)$.

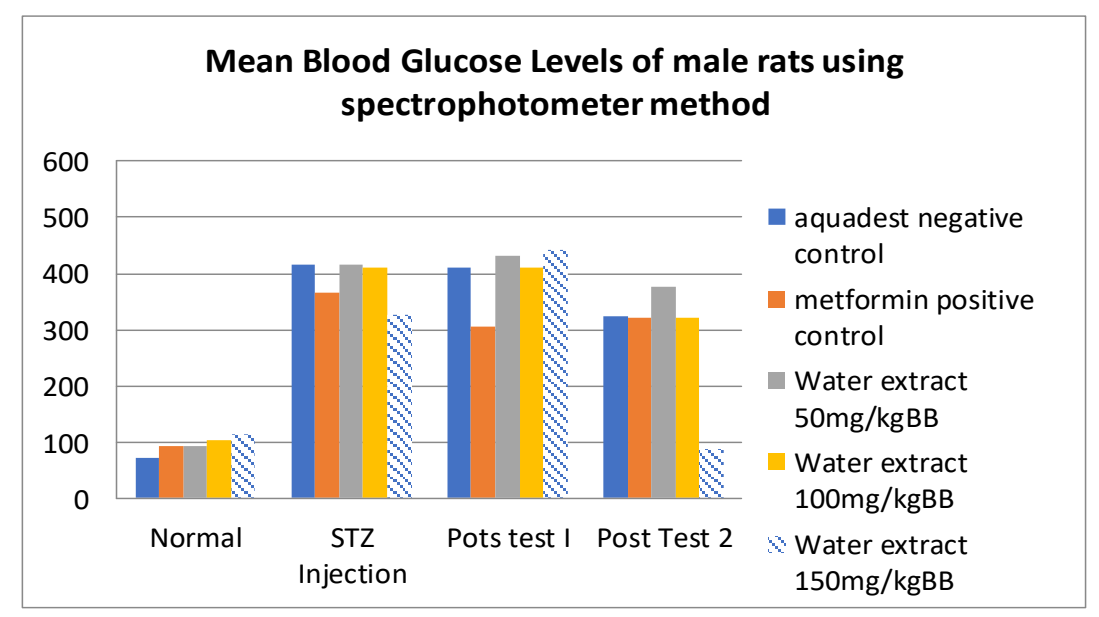

Figure 1 


\section{Mean Blood Glucose Levels of female rats using spectrophotometer method}

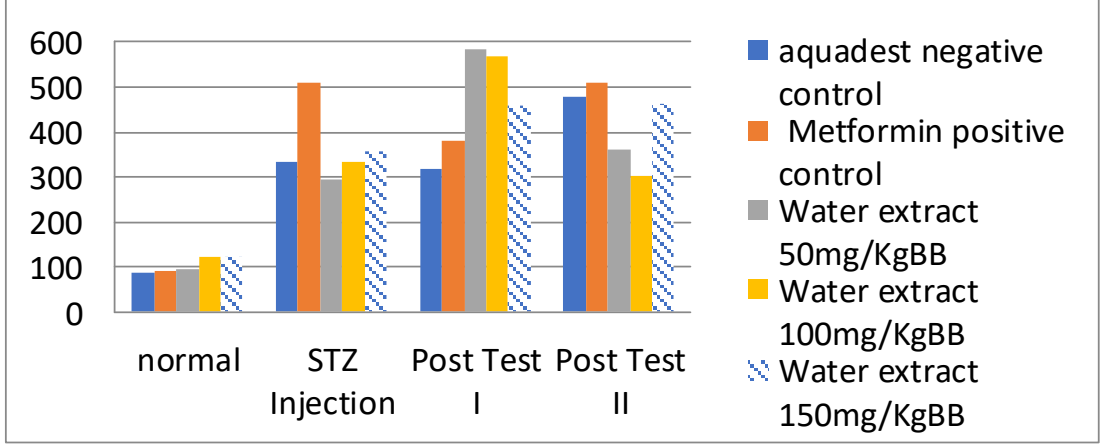

Figure 2

The results of Post test 1 in male rats decreased the lowest blood glucose levels in the rats shown by the positive control group metformin, with an average of 305.6. While the female rats in post test 1 showed negative control of aquades showed the lowest decrease in blood glucose with an average of 333. In post test 2 , the lowest blood glucose levels in male rats were shown by the water extract of Lannea coromandellica leaves 150mg / kgBW with an average of 87,2 . Meanwhile, female rats were shown by the water extract of Lannea coromandellica leaves $100 \mathrm{mg} / \mathrm{kg}$ BW with an average of 301.33 .

The results of observations of liver and pancreas macros in white rats can be seen in Table 2. There was no difference in the observed results between male and female white rats in all groups.

Histological observations of liver and pancreas in white rats in almost all groups treatment, both male and female rats showed the same changes. Changes can be seen in Table 3 .

The effectiveness of Lannea coromandellica leaves extract can be seen in tables 5 and 6 through the Kruskal-Wallis test. The Kruskal-Wallis test was used because the data were not normally distributed, where from the normality test results $\alpha>0.05$.

The results of the Kruskal-Wallis test on male and female rats showed no significant difference in decreasing blood glucose levels in the water extract of Lannea coromandellica leaves 50, 100, and $150 \mathrm{mg} /$ kgBW both on day 7 and day 14 .

The results of phytochemical tests showed that in the water extract of Lannea coromandellica leaves contain flavonoids, steroids, phenolics, saponins, tannins, and alkaloids. As reported by Kartasapoetra (1992), that in the plant Lannea coromandellica (Houtt.) Merr. contains flavonoids, saponins and tannins (Kartasapoetra, 1992) Fadliah et al. (2019) also stated that the water extract of Lannea coromandellica leaves contains saponins, flavonoids, polyphenols and tannins (Fadliah et al., 2019) while the steroid and alkaloid content in the water extract of Lannea coromandellica leaves has not been reported.

The results showed that the blood sugar levels of the rats experienced changes after being injected with STZ (pre test) and after measuring blood glucose levels post test I and post test II although after going through the Kruskal-Wallis test the changes did not show a significant difference in the administration of leaf water extract. Javanese wood during post test 1 and post test 2 .

Changes in blood sugar levels after STZ injection, indicating that mice are in a hyperglycemic state, this is because STZ can damage $\beta$ (beta) cells of pancreatic Langerhans. STZ compounds have a long half-life and are not easily oxidized. STZ works by forming free radicals that are highly reactive, causing damage to cell membranes, proteins and DNA which cause insulin reproduction problems in pancreatic beta cells (Saputra et al., 2018; Wilson et al., 1988). STZ also enters pancreatic Langerhans beta cells via GLUT 2 (glucose transporter 2 ) and causes an increase in the number of atoms in the molecule into a longer and more branched (alkylated) molecule.

Alkylation is formed by limiting the formation of adenosine triphosphate in the mitochondria due to the formation of free radicals, an increase in the xanthine oxidase enzyme and the inhibition of the krebs cycle (Szkudelski, 2001). The highest change in blood glucose levels of male rats was shown in the treatment group of male rats, the highest results were shown in the negative control group with aquades and water extract of Lannea coromandellica 
120 | Puetri et al.

Table 2 Macroscopic Observation Results of White Rat Organ

\begin{tabular}{lll}
\hline No & Organ Image & Description \\
\hline 1 & $\begin{array}{l}\text { All groups, both male and female rats, showed } \\
\text { no change (normal) }\end{array}$ \\
2 & All groups, both male and female rats, showed a \\
change in the color of the pancreas to pale white.
\end{tabular}

${ }^{a}$ Fetus mati yang sudah diresorpsi dan berukuran sangat kecil tidak dapat diamati

Table 3 Results of Histopathological Observation of white rat organ

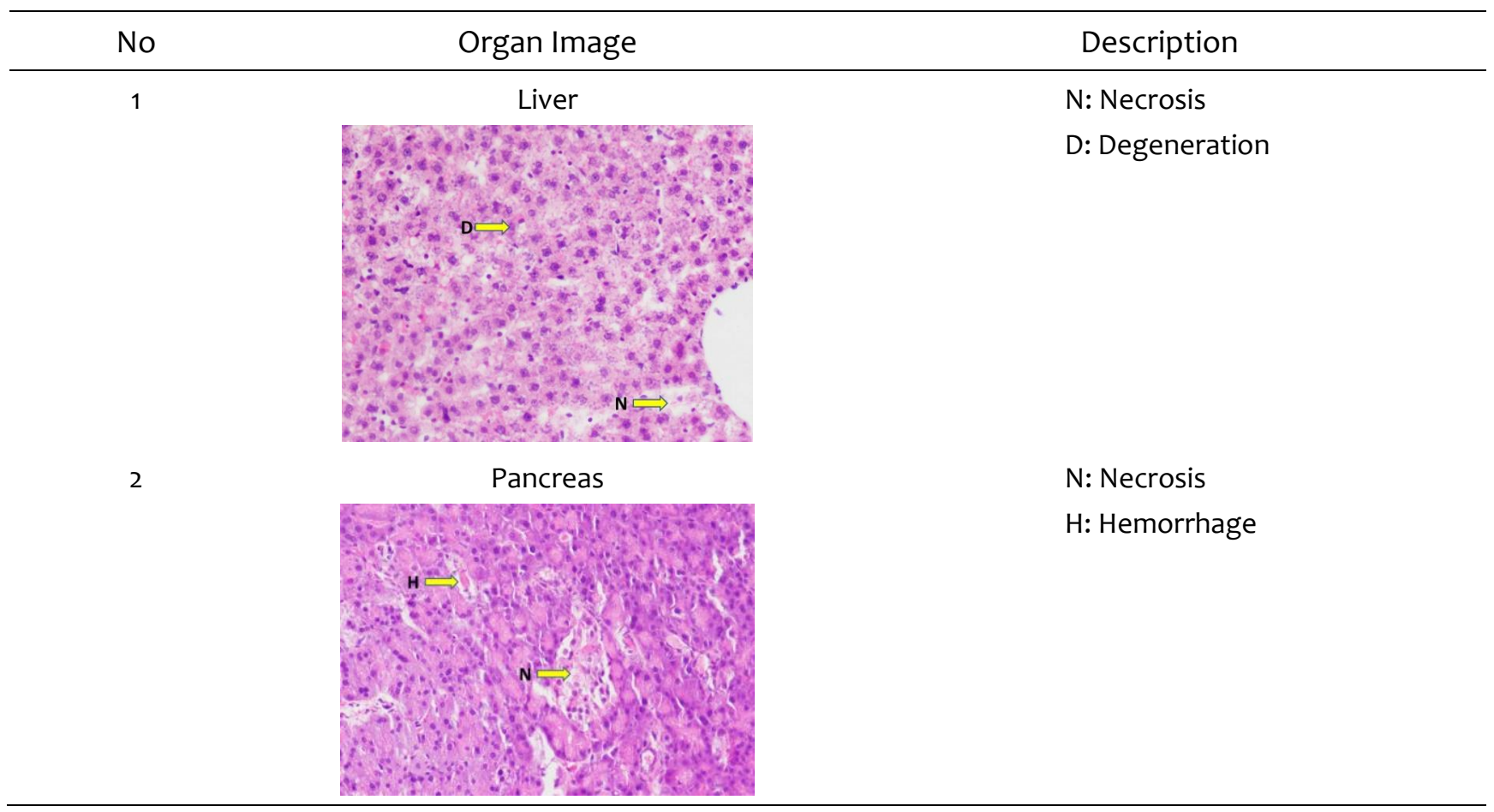

leaves 5omg / kgBW with an average of 415.2. In female rats the highest glucose levels were shown by the positive control group metformin with an average value of 509.33 .

Based on the results of the Kruskal-Wallis test, it was found that the value of $a>0.05$ indicated that there was no effect of giving the extract on changes in blood glucose levels in rats. This is presumably because the concentration of the extract given is a small amount, so it is not optimal in reducing blood glucose levels. Because when viewed from the average decrease in blood sugar levels, both male and female rats showed changes in decreasing blood glucose levels.

On day 14 male rats showed a decrease in blood glucose with an average value of 87.2 (water extract of Lannea coromandellica leaves $150 \mathrm{mg} / \mathrm{kgBW}$ ) which previously at the time of STZ injection (pretest) the blood glucose value reached 327.8. Whereas in female rats the decrease in blood glucose levels 
on the 14th day the lowest average value was 301.33 (water extract of Lannea coromandellica leaves $100 \mathrm{mg}$ ( kgBW) where the glucose value at the time of the pretest was 333. The difference in reduction that could be said was very different between the sexes. Male female rats are caused by the speed of drug metabolism in male mice and the stability of the body's biological conditions compared to female rats (Setiawan, 2010).

In macrocospic observations of the liver and pancreas of white rats, only the pancreatic organ changes. This change is caused by STZ induction. Where STZ works by inducing insulin deficiency by means of beta cell mechanism through the selective action of absorption through glucose transporters (GLUT 2) and beta cells, identical to death by necrosis and DNA alkylation. STZ is a good choice for experimental animals (Amir et al., 2016).

Based on the results of mouse histopathological observations in the pancreas and liver, there were changes in the pancreas and liver of the rats, where these changes were caused by the administration of STZ which could cause damage to the kidneys and liver (Deeds et al., 2011). Szkudelski (2001) states that the damage caused to the pancreas due to STZ administration begins with pancreatic beta cell damage (Szkudelski, 2001), the entry mechanism of STZ begins with the binding of STZ with GLUT-2 so that STZ into the cytoplasm of pancreatic beta cells results in depolarization of the mitochondria as a result of ion entry. $\mathrm{Ca}^{2+}$ and the use of excessive energy makes cells become energy deficient. This process causes insulin production to be disrupted so that insulin deficiency / deficiency occurs so that the glucose absorbed by the body cannot be processed completely which results in increased glucose levels in the body (Greenspan, 1998; Saputra et al., 2018). The histological image shows that degeneration is a normal condition in a cell, but necrosis and hemorrhage are abnormal phases that occur in cells due to certain mechanisms.

Based on the research results, it could be concluded: Delivery of water extract of leaves of wood java does not give effect to the decrease in blood glucose levels male and female rats for 14 days bytest Kruskal Wallis and hacyl phytochemical test shows the water extract of leaves of wood java contains flavonoids, steroids, phenolic, tannins, saponins and alkaloids. Therefore, further research is needed using a higher concentration to determine the effectiveness of giving water extract of Lannea coromandellica leaves in reducing blood glucose levels.

\section{ACKNOWLEDGEMENTS}

We express our gratitude for the research funding Riset Pembinaan Kesehatan (RISBINKES) 2019. Scientific Commission and Ethics Commission of Balai Litbang Kesehatan, Head of Balai Litbangkes Aceh, Experimental Animal Laboratory of $\mathrm{UI}$ and Puslitbang BTDK Jakarta, BBLK Jakarta, Chemistry Laboratory of FMIPA and FKH Unsyiah.

"All authors declare that there are no conflicts of interest".

\section{REFERENCE}

Amir A, Russell B, Liew JW, Moon RW, Fong MY, Vythilingam I, Subramaniam V, Snounou G, Lau YL. 2016. Invasion characteristics of a Plasmodium knowlesi line newly isolated from a human. Scientific Reports 6(1): 1-8.

BPOM RI. 2014. Peraturan Kepala Badan BPOM RI Nomor 7 Tahun 2014 Tentang Pedoman Uji Toksisitas Nonklinik Secara In Vivo.

Darmansyah D. 2015. Uji Toksisitas Subkronik Ekstrak Etanol Daun Kedongdong Pagar (Lannea Coromandelica (Houtt.) Merr.) pada Organ Hati Mencit Jantan. Skripsi S1. Universitas Sumatera Utara. Medan.

Deeds MC, Anderson JM, Armstrong AS, Gastineau DA, Hiddinga $\mathrm{HJ}$, Jahangir A, Eberhardt NL, Kudva YC. 2011. Single dose streptozotocin-induced diabetes: considerations for study design in islet transplantation models. Laboratory Animals 45(3): 131-140.

Fadliah S, Mu'nisa A, Rachmawaty R. 2019. Analisis Fitokimia Air Rebusan Daun Kayu Jawa (Lannea coromandelica). Bionature 19(1): 73-77.

Greenspan, F. 1998. Endokrinologi Dasar dan Klinik. $4^{\text {th }}$ Ed. EGC. Jakarta

Kartasapoetra. 1992. Tanaman Berkhasiat Obat. Pustaka Ilmu. Jakarta.

Loomis, Ted A. 1978. Toksikologi Dasar Terjemahan. Ketiga. IKIP Semarang Press. Semarang.

Puetri NR, Marlinda. 2017. The Effect of Ethanolic Extract from Lannea grandis Engl. Leaves in Change of Blood Sugar Levels of Alloxan-Induced Wistar Rats. Edited by H. Bacho. Beau Bassin, Mauritius. LAP Lambert Academy Publishing. Saarbrücken.

Saparinto C, Susiana R. 2016. Grow Your Own Medical Plant Panduan Praktis Menanam 51 Obat Populer di Pekarangan. Lily Publisher. Yogyakarta.

Saputra NT, Suartha IN, Dharmayudha AA. 2018. Agen diabetagonik streptozotocin untuk membuat tikus putih jantan diabetes mellitus. Buletin Veteriner 
122 | Puetri et al.

Udayana 10(2): 116-121.

Setiawan R. 2010. Pengaruh Pemberian Ekstrak Kelopak Bunga Rosela (Hibiscus sabdariffa L) Terhadap Penurunan Kadar Gula Darah Tikus Putih (Rattus Novergicus) yang Diinduksi Aloksan. Skripsi S1. Universitas Sebelas Maret. Surakarta.

Szkudelski T. 2001. The Mechanism of Alloxan and Streptozotocin Action in B Cells of the Rat Pancreas. Physiological Research 50(6): 537-546.

Widiyastuti Y. 2011. 100 Top Tanaman Obat Indonesia. Tawang Mangu: Kementerian Kesehatan RI. Balai
Besar Litbang Tanaman Obat dan Obat Tradisional. Karanganyar.

Wilson GL, Hartig PC, Patton NJ, LeDoux SP. 1988. Mechanisms of nitrosourea-induced $\beta$-cell damage: activation of poly (ADP-ribose) synthetase and cellular distribution. Diabetes 37(2): 213-216.

Yunsa B, Puetri NR, Marlinda M. 2017. Uji Toksisitas Akut (LD50) Ekstrak Daun Kuda-Kuda (Lannea grandis Engl.) terhadap Tikus Wistar (Risbinkes) Laporan Penelitian. Loka Penelitian dan Pengembangan Biomedis Aceh. Banda Aceh. 